\title{
Food and water gaps to 2050: preliminary results from the global food and water system (GFWS) platform
}

\author{
R. Quentin Grafton • John Williams • Qiang Jiang
}

Received: 12 January 2015 / Accepted: 18 February 2015 / Published online: 8 March 2015

(C) The Author(s) 2015. This article is published with open access at Springerlink.com

\begin{abstract}
We review the pressures, threats and risks to national food and water availability based on projected global population growth to 2050 using the Global Food and Water System (GFWS) platform. This platform is used to explore food availability deficits for scenarios of crop production under various fertiliser, water use, crop improvement and land use options. The GFWS platform can be used to assess the effects of annual crop productivity improvements on food production and incorporates data from 19 major food-producing nations to generate projections of food and water gaps in irrigated agriculture. Preliminary results indicate that crop-based food supply is able to meet food requirements by 2050 , but this is only possible with 'input intensification' that includes increased rates of water in irrigated agriculture and fertiliser use per hectare and continued annual growth of crop yield productivity improvement of at least $0.5 \%$ per year over the period. Increased water withdrawals for agriculture with input intensification would, without any increases in withdrawals in the manufacturing, mining or household uses, place the world above the safe operating space in terms of overall water use by 2050 . Even with input intensification, large and increasing crop-based food availability deficits to 2050 can be anticipated in some countries and regions within the group of 19 countries, especially in South Asia.
\end{abstract}

R. Q. Grafton $(\bowtie) \cdot J$. Williams

Crawford School of Public Policy (Bldg. 132), The Australian

National University, Acton ACT 2601, Australia

e-mail: Quentin.grafton@anu.edu.au

Q. Jiang

Sichuan University, Chengdu, China
Keywords Food security $\cdot$ Water supply $\cdot$ APSIM

\section{Introduction}

The global food system is experiencing an unprecedented confluence of pressures that may increase over the next 40 years given the substantial projected increases in food production, energy use and water use out to 2050 (Foresight 2011). Growth in agricultural production under business as usual will contribute to the planet approaching or even surpassing its safe operating space in terms of biodiversity, climate change and the nitrogen cycle (Rockström et al. 2009). Thus, balancing future food demand and supply and managing for variability, including adapting to climate change, in ways that protect the most vulnerable (Ivanic and Martin 2008) and that are also sustainable in terms of use of energy, water, biodiversity and ecosystem services must be a first order policy priority (Godfray et al. 2010; Tilman et al. 2011; Foresight 2011).

On the demand side, global population size is projected to increase from nearly 7.2 billion today to 8 billion by 2030 , and more than 9 billion by 2050 under a medium growth scenario (United Nations 2013). Per capita income growth of $3 \%$ per year will also more than double world income by 2050 . More people and higher average incomes will result in greater food consumption and changes in diets with a greater proportion of meat and dairy consumed by an emerging middle class.

Various measures exist of what will be the required increase in food supply, quantified in terms of production, to meet the increase in food demand by 2050 and range from $60 \%$ upwards (IAASTD 2008; Tilman et al. 2011; FAO 2011a; Alexandratos et al. 2012; Ray et al. 2013) noting that these are effective demand increases and do not presume there are no undernourished by 2050. Increased food production will, in turn, require greater inputs whether it be land, water 
or energy, or a combination of these inputs. Thus, whatever is the required increase in food production, competition for land, water and energy will intensify, especially in terms of production for food versus production for biofuels (To and Grafton 2015; UNEP 2014).

Overlaying the food supply challenge is the issue of environmental sustainability due to land, biodiversity and water degradation, especially soil and fertility loss (Rickson et al. 2015), decline in groundwater and river flows, and water pollution. While undesirable in themselves, land, biodiversity and water degradation have, and will continue, to restrict growth in food production in the coming decades.

In this paper, we examine the gap between projected global food demand and projected food supply. In the second section, Global Food Demand and Supply, we review the literature and recent projections on food supply and demand. We present the Global Food and Water System (GFWS) platform in the third section and, in the fourth section, preliminary results from the platform and possible scenario-based food and water gaps out to 2050 . In the penultimate section we discuss the implications of our findings in terms of food supply and offer our conclusions in the final section.

\section{Global food demand and supply}

While there is genuine concern about how the anticipated increase in food demand will be met by 2050 , we observe that globally agriculture has successfully responded to increased food demand from rapid population growth over the past decades. Food supply has more than tripled since 1960 and continues to rise at a global level (FAO 2011b). Nevertheless, prospects for the future are increasingly uncertain because some of the past production increases have been at the expense of degraded or destroyed ecosystems and depletion of the natural resource base on which agriculture is, ultimately, dependent. Further, it is by no means clear whether additional increases in food supply are possible without further damage to local, regional and global ecosystems services (IAASTD 2008; Williams and McKenzie 2008; Beddington 2010; Tilman et al. 2011).

Food demand to 2050

Understanding the capacity of agricultural systems to feed the world requires multiple tools and methods for projecting future food demand. Tilman et al. (2011) estimated global food demand to 2050 using FAO and national projections for population and GDP with a predicted relationship between GDP and calorie and protein intake per capita. Using this relationship, they forecast a 100-110\% increase in global demand for food crops from 2005 to 2050. Alexandratos et al. (2012) project a lower increase in the aggregate volume of world agricultural production by 2050 . Table 1 shows their findings that stipulate required increases within the next 50 years ranging from $45 \%$ for cereals to $89 \%$ for oil crops. Demand for food is driven mainly by population growth, but also by income growth. Using cross-country food expenditures, Muhammad et al. (2011) found that the marginal share of income spent on food declines with increasing per-capita income. Income growth also leads to a change in diets with a shift toward more diverse diets that include a larger share of animal protein, fats and oils. For instance, China, which has witnessed a very rapid growth in per-capita income over the past two decades, has also seen a sharp growth in the consumption of livestock products.

Simulating possible agricultural futures requires analytical tools that can represent world agriculture in a comprehensive way and reproduce the main structural drivers of demand and supply. A recent study by Valin et al. (2014) compared food demand projections in 2050 for various regions and agricultural products under harmonised scenarios of socioeconomic development, climate change, and bioenergy expansion. In their reference scenario (SSP2) that specifies a world population of 9.3 billion by 2050 (42\% higher than the 2005 level) and a more than doubling in average income per capita globally, from 6,700 USD in 2005 to 16,000 USD in 2050, food demand increases by $59-98 \%$ between 2005 and 2050. This is slightly larger than the most recent FAO (2011) projection of the required production increase of $54 \%$, not accounting for climate change from 2005/2007.

The results of Valin et al. (2014) largely depend on the selected scenario. For instance, the projected demand for animal calories varies between $61 \%$ and $144 \%$ with these differences caused by alternative demand system specifications, and in particular by income and price elasticities. Their modelling shows that variation in food demand is more sensitive to socioeconomic assumptions than to climate change or bioenergy development scenarios.

Affordability of food is as important as food availability. Consequently, real food prices constitute another important driver of food demand. High commodity prices not only affect food consumption in developing regions, but also consumption choices of final food products. Food demand is also influenced by other drivers, including education, local traditions, urbanisation and trade liberalisation. Demographic factors, such as age and gender distribution, as well as physical

Table 1 World Production of Major Agricultural Products

\begin{tabular}{llcl}
\hline $\begin{array}{l}\text { Major } \\
\text { Products }\end{array}$ & $\begin{array}{l}\text { 2005-2007 (million } \\
\text { metric tonnes) }\end{array}$ & $\begin{array}{l}\text { 2050 (million } \\
\text { metric tonnes) }\end{array}$ & $\begin{array}{l}\text { Per Cent } \\
\text { Change }\end{array}$ \\
\hline Meat & 258 & 455 & +76.4 \\
Sugar & 195 & 341 & +74.9 \\
Oil Crops & 149 & 282 & +89.3 \\
Cereals & 2068 & 3009 & +45.5 \\
\hline
\end{tabular}

Alexandratos and Bruinsma (2012) in Fig. 1.4 
activity and levels of obesity also lead to different metabolic requirements and determine patterns of over- or under-consumption. This is also true of the share of the food products 'wasted' or not consumed by people (FAO 2011a; Foley et al. 2011).

\section{Food supply to 2050}

Increasing global food production by at least $50 \%$ by 2050 is arguably the greatest challenge for food security. Land and water resources are much more stressed than in the past and there are key challenges in terms of soil degradation and salinisation of irrigated areas. Further, there is increasing competition of inputs (land, water and energy) for uses other than for food production (Alexandratos et al. 2012).

Fischer et al. (2014), in a comprehensive global analysis provide evidence that crop yield increases of $1.1 \%$ p.a. (relative to 2010 yield) are the minimum required to feed the world in terms of average food availability by 2050 at real prices close to those in 2010. By comparison, the current average global crop yield growth of the world's major cereals varies between $0.9 \%$ and $1.6 \%$ per year (Ray et al. 2013) and the rates of increase have fallen in the past two decades (Fischer et al. 2014). The future challenge is whether the lower rates of crop farm yield increase, together with modest increases in cultivated land, will be sufficient to meet the increased food demands by 2050 .

Climate change poses risks to future food supplies. This is not just because of higher temperatures on yields, which is moderately negative for some plants. Rather, the difficulty in terms of food supply lies in climate variability through a possible increase in the number of extreme weather events (Grafton and Keenan 2014; Chartres and Noble 2015). Extreme events would likely make food prices and food supply more variable than in the most recent few decades. As a result of these possible shocks and uncertainties, Fischer et al. (2014) conclude that the target for global crop farm yield increase should be set closer to $1.3 \%$ per year to ensure sufficient food availability by 2050 .

Given current constraints in key inputs (land and water) and the consequences of high input uses, such as fertilisers, the present sustainability of the food production system is being questioned in areas of the world with intensive agriculture (Alexandratos et al. 2012; Ray et al. 2013). Per capita availability of suitable land in 2050 is likely to be plentiful in only a few regions (FAO 2011; UNEP 2014). Consequently, yield gap reductions, technological improvements and efficiency gains will be needed. This is especially relevant in tropical locations where soil nutrient availability and retention against leaching under soils with low, $\mathrm{pH}$ dependent exchange capacity are found (Gillman and Sumpter 1986). While fertilisers will play an increasingly important role in overcoming yield gaps, complementary approaches may be needed to promote 'sustainable intensification' of agricultural production (Nature 2010; Royal Society 2009; Godfray et al. 2010).

The International Food Policy Research Institute (IFPRI) has undertaken a comparative analysis using a baseline scenario, which assumes that countries maintain their current trends in agricultural policies and investments from 2010 to 2050 (IFPRI 2012a). The major drivers of this baseline scenario are income growth, population increase, productivity gains in many agricultural activities, and biofuel sector expansion. Under the IFPRI baseline, food security is projected to improve in most regions.

IFPRI also examined three other scenarios that include: (1) higher agricultural productivity; (2) a higher-energy-prices scenario; and (3) lower meat demand. The multiple scenarios show that different choices with regard to agricultural investment, energy, and food consumption can result in very large variation in terms of food prices, trade, and food security. Importantly, higher investment in agricultural research that boosts productivity growth is projected to substantially improve global food availability (Fischer et al. 2014).

\section{Energy and food supply}

Steinbuks and Hertel (2013) have modelled links between energy and agriculture through fossil fuel use in fertiliser and the energy services in fuels, processing and transportation on and off the farm. Their results suggest that long-term uncertainty in energy price forecasts translates into variation in land use change of as much as 400 million hectares. This is four times higher compared to the variation in land use change from uncertainty in climate impacts on agricultural yields, and twice as high as the maximum variation in land use change from uncertainty in greenhouse gas emissions targets.

They observe that natural gas prices affect the use of fertilisers, which in turn, triggers an endogenous response of land intensification. Oil prices are a key long-run determinant of biofuel demand, and higher oil prices result in a larger demand for land used in biofuel production. Energy prices also indirectly affect land use decisions by shifting consumption between land-based goods and services and other sectors of the economy.

The importance of energy in food production is highlighted in IFPRI's higher-energy-prices scenario. This scenario assumes a $100 \%$ increase in crude oil prices by 2035 . Under this assumption of higher oil prices, biofuel production is more profitable and this, in turn, increases the global demand for feedstocks in the biofuel sector by about two-thirds by 2035 . Another important link is the effect of energy prices on fertiliser prices. IFPRI shows that higher energy prices would significantly raise the cost and the price of key agricultural commodities. In turn, this would lower global crop production with potentially serious consequences for food security, as shown in Table 2. 
Table 2 Projected differences in food security indicators by 2050 under higher energy prices scenario compared with the baseline scenario in which current energy prices and policies are maintained ( $\%$ change)

\begin{tabular}{llc}
\hline Region & $\begin{array}{l}\text { Number of malnourished } \\
\text { children }\end{array}$ & $\begin{array}{l}\text { Population at } \\
\text { risk of hunger }\end{array}$ \\
\hline East Asia and Pacific & +4 & +6 \\
Europe and Central Asia & +5 & +2 \\
Latin America and Caribbean & +8 & +17 \\
Middle East and North Africa & +8 & +8 \\
South Asia & +2 & +19 \\
Africa South of Sahara & +4 & +15 \\
World & +4 & +14 \\
\hline
\end{tabular}

IFPRI (2012b), their Chapter 8 and Table 4

Table 2 indicates that much higher energy prices increase the number of malnourished children and the population at risk of hunger in all regions of the world. Part of the challenge of high energy prices is the so-called 'ratchet effect' used to describe the enhanced coupling of oil and food prices in recent years (Sinn 2012). This coupling can arise because, while food can directly substitute for energy, through biofuel production, energy cannot directly be converted into food except indirectly as an input into agricultural production such as through fertiliser applications. Thus, when the price of oil rises sufficiently there can be an incentive for farmers to switch away from producing food and instead to producing biofuels (To and Grafton 2015).

\section{The global food and water system (gfws) platform}

The Global Food and Water System (GFWS) platform developed by the authors is designed so users can easily explore the relationship between crop yields, genetic improvement, use of water and fertiliser and land area, on the gap between food production and food demand, along with the resultant gap between agricultural water demand and supply out to the year 2050. The exogenous drivers of the platform are per capita food consumption values (kcal/person/day) and human population projections that determine food demand. Food supply is calculated by multiplying crop yield per hectare (determined by fertiliser and water use) by land area per crop adjusted by crop yield improvements. Agricultural water use is determined by land use, crops and area under irrigation as defined by FAO statistics noting that land under informal irrigation, especially in Africa, would increase the estimated global irrigated land area.

In the current version of the GFWS platform, 19 countries are included (Argentina, Australia, Bangladesh, Brazil, Canada, China, Egypt, France, India, Indonesia, Mexico, Pakistan, Poland, Russia, Thailand, Turkey, United States, Ukraine and Vietnam) as well as their major crops: wheat, rice, maize, sorghum, barley, oats and soybean. Additional countries will be added as the model is further developed. Crop yield improvements can be scaled by the user, based on the scenario that they choose to simulate in terms of linear annual productivity improvements. The land available for cropping, both as dryland and irrigated land, can be scaled relative to the use of land in 2007-2010. This allows the GFWS platform to assess the effects of key water and nutrient drivers on water surplus and deficit based on national data, and possible changes to land use.

Component and computation procedures

The GFWS platform uses a crop production model, extensive climate, and crop and soil data to build and integrate agricultural databases, which are then interrogated by an Excel-based spreadsheet. As depicted in Figs. 1 and 2, this platform consists of a crop yield database generated by using a biophysical crop model, a suite of set-up scenario designs built on national agricultural databases, and both are drawn together by an Excel interface. Specifically:

(1) The crop yield database contains crop yield data generated from crop yield simulations from the Agricultural Production Systems Model (APSIM) under different combinations of water and nitrogen fertiliser use.

(2) Scenarios in the GFWS model are a range of assumptions that will determine the food and irrigation water demands in 2050. The purpose of the scenarios is to project a series of future food and water demands within a reasonable range of assumptions. Scenarios in the GFWS platform include projections on population growth, calorie demand, dietary change, international trade and irrigation techniques. All data in scenarios are obtained from the OECD, UN or FAO.

(3) The Excel interface is used to design scenarios, and also analyses the future water and food gaps through the integration of data from the setup scenario and the crop yield database.

The underlying database and crop yield calculations are generated from APSIM which is described by McCown et al. (1995) McCown et al. (1996) and Keating et al. (2003). The APSIM crop simulation 'toolbox' is well documented and has been widely used for more than two decades (see www.apsim.info/Products/Publications.aspx).

Key inputs and outputs

The GFWS platform focuses on how to produce food based on selected irrigation and fertiliser rates. The genetic crop yield improvement is applied as an annual productivity change in yields over a range from 0 to $3 \%$ per year. We use a linear annual increase, as recommended by Grassini et al. (2013) because it best describes crop yield trends since 1960. Fischer et al. (2014) suggest that a minimum linear crop yield improvement target of 
Fig. 1 A diagrammatic representation of the GFWS platform and its primary components

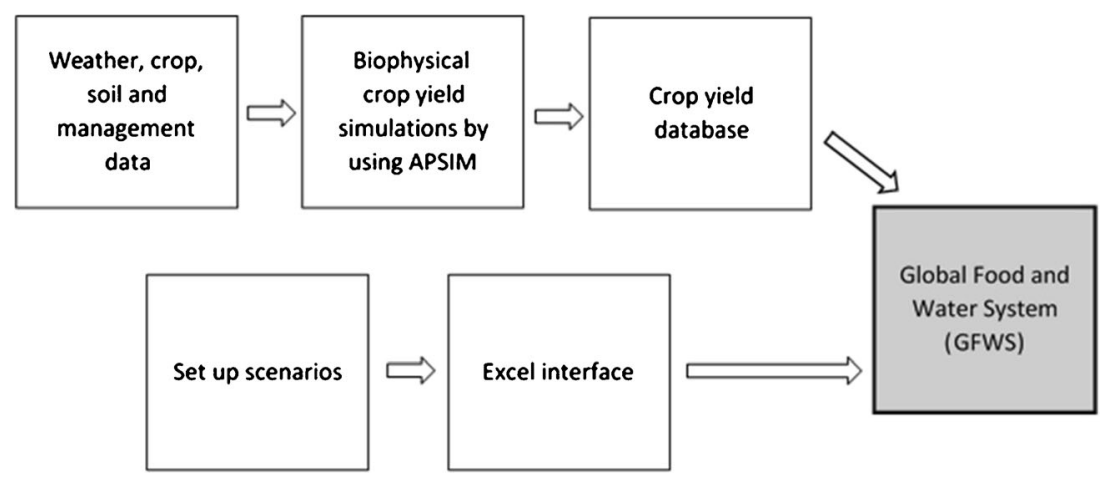

between 1 and $1.5 \%$ per annum is required over the next 50 years to satisfy future food demand.

Users of the GFWS platform can increase irrigation rates from $0 \mathrm{~mm}$ to $500 \mathrm{~mm}$ using furrow, sprinkler and drip application methods for irrigated crops. Flooded paddy rice is treated appropriately using the APSIM rice module (Bouman and Van Laar 2006). In both dryland and irrigated crops, elemental nitrogen fertiliser rates can be assessed over the range from $0 \mathrm{~kg} / \mathrm{ha}$ to $250 \mathrm{~kg} / \mathrm{ha}$. The weather data used to drive the APSI $\mathrm{M}$ models is drawn from SWAT current climate database at http://globalweather.tamu.edu/ while the planting and harvesting calendar for irrigated crops is obtained from FAO (FAO 2011b) information and database at www.fao.org/nr/ water/aquastat/main/index.stm.

\section{Scenarios}

\section{Population growth}

The population growth specification is adopted from the projections made available by the World Bank obtained from http:// data.worldbank.org/data-catalog/population-projection-tables. Population projection from the World Bank shows population growth projections and other demographic data from 2010 to

Fig. 2 Simplified structure of the computational procedures used in the GFWS platform
2050, at five-year intervals. Once the user selects the country, the projected population until 2050 for this country will be used as the future population number in the GFWS platform.

\section{Food requirement}

Food requirement is expressed as kilocalories (kcal) per capita per day. The per capita food availability data is from the FAO per capita food requirement forecast and obtained from www. fao.org/docrep/009/a0607e/a0607e00.htm.

\section{Meat consumption}

In some emerging economies, such as China, diets are shifting toward increased consumption of meat and dairy. This, in turn, requires more crop and pasture production than if the food were consumed directly as cereals, and also demands greater water use for irrigation. At present, the GFWS platform uses the $\mathrm{FAO} \mathrm{kcal/person/day} \mathrm{projections} \mathrm{in} \mathrm{its} \mathrm{projections} \mathrm{without}$ accounting for changes in diets. This deficiency in our modelling is work in progress. The importance of accounting for dietary changes is noted by Bajželj et al. (2014) who highlight the challenge of intensification of agriculture while reducing GHG emissions coupled with increasing agricultural land use.

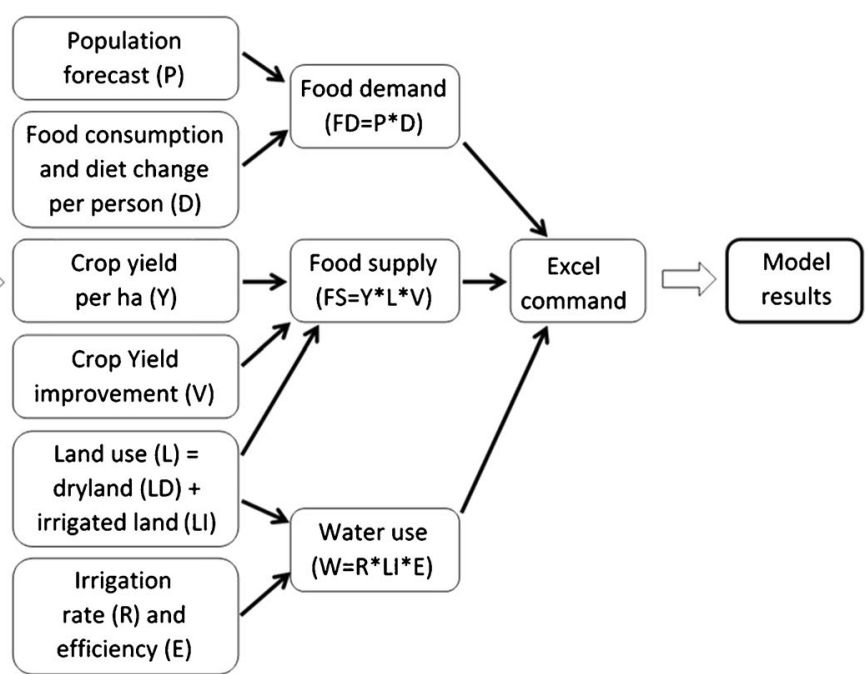




\section{Food exporting}

Some countries, like Australia, are traditional food exporting countries and will likely continue to export food to other countries. By contrast, imported food is crucially important for some countries, such as those in the Middle East and North Africa. The GFWS platform recognises the significant role of food exporting and assumes the food exporting countries will at least sustain their net food export levels at their historical levels. The food exporting data we use is made available by FAO (FAO 2011b) information and database at http://faostat. fao.org/site/342/default.aspx.

\section{Land use scenario}

GFWS uses the amount of arable land as the land-use constraint for each country made available by the World Bank. For each crop, the historical land use represents a baseline. Users can increase land use for either dryland or irrigated cropping in five increments from 10 to $50 \%$ of current baseline areas. The arable land data we use is made available by World Bank information and database at http://search. worldbank.org/quickview? name $=\% 3 \mathrm{Cem} \% 3 \mathrm{EArable} \% 3 \mathrm{C} \%$ $2 \mathrm{Fem} \% 3 \mathrm{E}+\% 3 \mathrm{Cem} \% 3 \mathrm{Eland} \% 3 \mathrm{C} \% 2 \mathrm{Fem} \% 3 \mathrm{E}+\%$ 28 hectares $\% 29 \& \mathrm{id}=\mathrm{AG} \cdot \mathrm{LND}$.ARBL.HA\&type= Indicators \&cube_no $=2 \&$ qterm $=$ Arable + land.

Computational procedures

\section{Food requirements and supply}

GFWS forecasts food requirements by using population growth and food requirements growth such that the national food demand $\left(\mathrm{FD}_{\mathrm{ij}}\right)$ in year $\mathrm{i}$ and country $\mathrm{j}$ in kilocalories is given by:

$\mathrm{FD}_{\mathrm{ij}}=\mathrm{P}_{\mathrm{ij} *} \mathrm{D}_{\mathrm{i}}$

where $\mathrm{P}$ is the national population forecast and $\mathrm{D}$ is the food requirement forecast in kilocalories per person per year. If we drop the time subscript for convenience, the GFWS platform projects national food supply by using simulated crop yields with land use and crop yield improvements such that the domestically produced food supply for crop $\mathrm{k}$ in country $\mathrm{j}\left(\mathrm{FS}_{\mathrm{kj}}\right)$ is given by:

$\mathrm{FS}_{\mathrm{kj}}=\mathrm{Y}_{\mathrm{kmnj}} * \mathrm{~L}_{\mathrm{kj}} * \mathrm{~V}_{\mathrm{k} \mathrm{j}}$

where $\mathrm{Y}$ is the crop yield per ha (simulated by APSIM) of crop $\mathrm{k}$ in country $\mathrm{j}$ for a given fertiliser rate per hectare defined by $\mathrm{m}$ and a rate of water application per hectare by $\mathrm{n}$ that varies by land type; $\mathrm{L}$ is the land area used in dryland (LD) and irrigated production (LI) such that $\mathrm{L}=\mathrm{LI}+\mathrm{LD}$ for crop $\mathrm{k}$ in country $\mathrm{j}$; and $\mathrm{V}$ is the linear annual crop yield improvement for crop $\mathrm{k}$ in country $\mathrm{j}$.
A food availability deficit occurs when FD exceeds FS. Given losses on farm and food wastage, neither of which are calculated in the GFWS platform, and estimated by the FAO to be as much as 1.3 billion tonnes per year globally, a food availability deficit may still exist even if FS is greater than FD.

\section{Water use}

GFWS forecasts national agricultural water use $\left(\mathrm{W}_{\mathrm{kj}}\right)$ based on the existing climate for crop $k$ in country $j$ by using irrigation rates and land use areas as follows:

$\mathrm{W}_{\mathrm{kj}}=\mathrm{R}_{\mathrm{kj}} * \mathrm{LI}_{\mathrm{kj}} * \mathrm{E}_{\mathrm{j}}$

where $\mathrm{R}$ is the irrigation rate for crop $\mathrm{k}$, in country $\mathrm{j}$ while LI is area of irrigated land for crop $k$ in country $j$ and $E$ is the water use efficiency rate which is determined by the choice of the method of irrigation for crop k in country $\mathrm{j}$.

All the above procedures are depicted in Fig. 2 for each country and crop. Food supply in $\mathrm{kg} / \mathrm{ha}$ by crop is converted into kilocalories using data available at www.fao.org/docrep/006/ Y5022E/y5022e04.htm to calculate food supply or deficits.

\section{GFWS platform: preliminary results}

Preliminary results from the GFWS platform are provided in Fig. 3. The results include eight different scenarios and the projected global food demand or deficit, as generated by the platform. All eight scenarios in Fig. 3 specify a water application rate in irrigated agriculture of $200 \mathrm{~mm} / \mathrm{ha}$.

In Scenarios 1 to 5 , both irrigation and dryland cropping specify a $50 \mathrm{~kg} /$ ha of elemental nitrogen, but with alternate linear annual rates of crop yield improvement of $0.5 \%, 1.0 \%, 1.25 \%$, $1.5 \%$ and $2.0 \%$, respectively. In Scenario 6, $150 \mathrm{~kg} /$ ha of nitrogen is specified at a rate of annual crop improvement of $1.25 \%$ while in Scenarios 7 and 8, $0 \mathrm{~kg} /$ ha of nitrogen is specified with a crop yield improvement of $1.25 \%$ and $0.5 \%$, respectively.

The different series show the effects of nitrogen fertiliser rates on food surplus or deficit out to 2050 as well as the relative importance of the rate of linear crop yield improvement. Scenarios 3, 6 and 7 show the substantial and positive effects on food supply if nitrogen fertiliser increases from 0 to 50 and to $150 \mathrm{~kg} /$ ha with an annual linear rate of crop yield improvement of $1.25 \%$. At $0 \mathrm{~kg} /$ ha of nitrogen and a $0.5 \%$ annual rate of crop yield improvement, as shown in Scenario 8, food deficits are predicted consistently out to 2050 . The results show that without adequate rates of fertiliser application, despite reasonable levels of irrigation water and crop productivity improvement, food supply gaps will exist over the entire period to 2050. In other words, substantial improvements in potential crop yields and water use cannot compensate for the nutrients needed to ensure the genetic 
Fig. 3 A set of projections of surplus or deficit in food production (billions kcalories) for eight scenarios for dryland and irrigated cropping based on 19 countries. In all scenarios we adopted an irrigation regime of $200 \mathrm{~mm}$ of water. In Scenarios 1 to $5,50 \mathrm{~kg} / \mathrm{ha}$ of $\mathrm{N}$ were examined under five annual rates of crop yield improvement of $0.5 \%$, $1.0 \%, 1.25 \%, 1.50 \%$ and $2.0 \%$ respectively. In Scenario 6, $150 \mathrm{~kg} / \mathrm{ha} \mathrm{N}$ was examined at a rate of annual crop improvement of $1.25 \%$ while in Scenarios 7 and $8,0 \mathrm{~kg} / \mathrm{ha}$ of $\mathrm{N}$ was examined at rates of crop yield improvement of $1.25 \%$ and $0.5 \%$ respectively

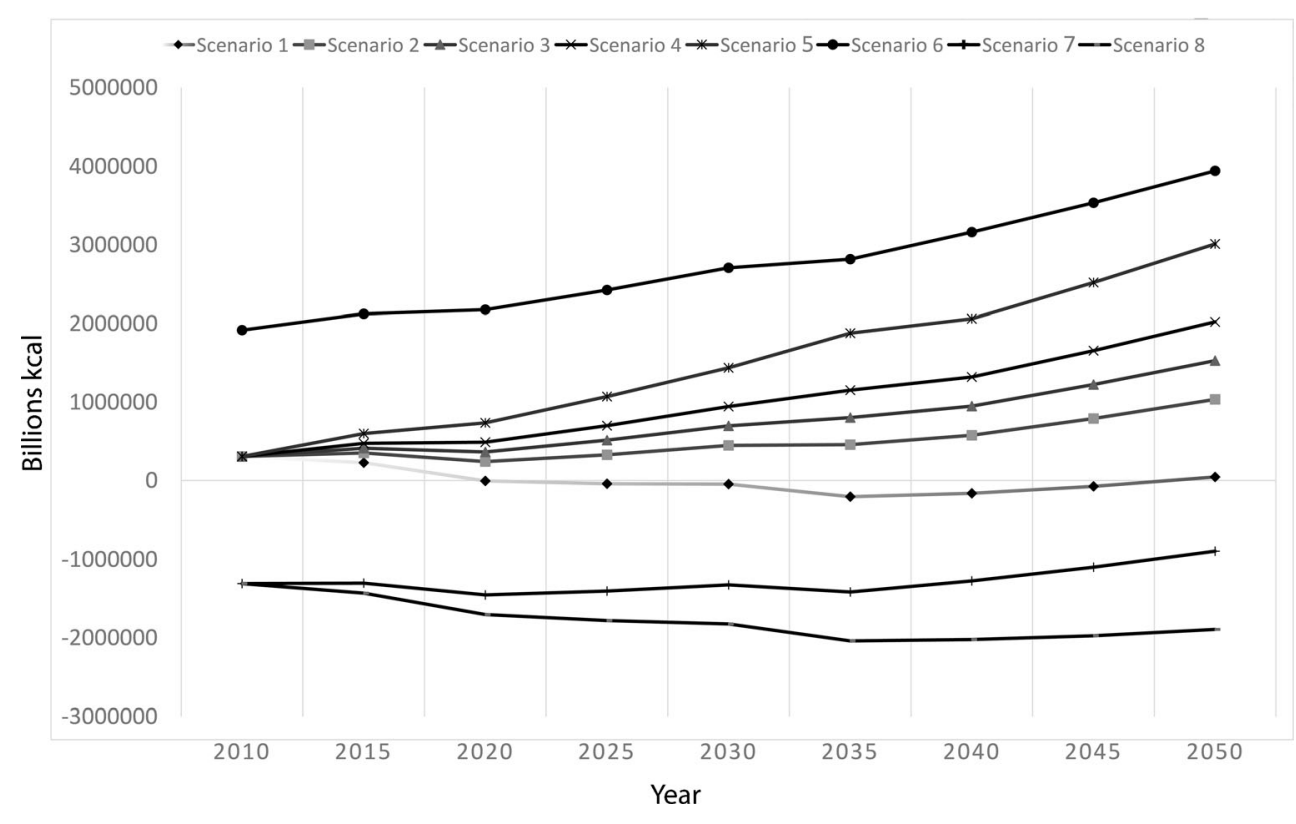

capacity of the crop for yield is fully exploited and that global food deficits are avoided.

The results presented in Scenarios 1 to 5 show the effects of increasing rates of crop yield improvements on food surplus or deficit. At an average of $50 \mathrm{~kg} / \mathrm{ha}$ of nitrogen, overall food production can be in surplus, but only if the rate of crop yield improvement exceeds $0.5 \%$. Crop yield improvements of $0.5 \%$ or less, as shown in Scenario 1, result in food deficit out to 2050. Annual linear crop yield improvement rates of $1.0 \%$ to $1.25 \%$ and fertiliser rates of $50 \mathrm{~kg} / \mathrm{ha}$ of nitrogen are sufficient to maintain a food supply in surplus out to 2050 based on our assumption of no changes in diets.

A much higher rate of nitrogen fertiliser use at $150 \mathrm{~kg} / \mathrm{ha}$ could generate a large and increasing surplus at a crop yield improvement rate of $1.25 \%$. While not shown in Fig. 3, a low rate of annual crop yield improvement of $0.5 \%$ at $150 \mathrm{~kg} / \mathrm{ha}$ of nitrogen fertiliser application also maintains a food surplus through to 2050. Overall, our results suggest that provided sufficient nutrients are present, crop improvements through genetics or improved agricultural management can be expressed and will overcome possible future food availability deficits.

Figure 4 provides a country breakdown of the food surplus/ deficit for each of the 19 countries for 2010 and 2050. Under Scenario 1 we assume 'moderate' irrigation of $200 \mathrm{~mm} / \mathrm{ha}$, basic nitrogen fertilisation of $50 \mathrm{~kg} / \mathrm{ha}$ and a low rate of linear crop yield improvement of $0.5 \% / y e a r$. All nations under this option, which generates surplus in 2010 , see a reduction in surplus by 2050 , and many cross over into deficit. All countries in deficit in 2010 move to a larger deficit in 2050. The most striking finding is the projected food deficit in South Asia (India and Pakistan) under this scenario.

Figure 5 shows the country-by-country surplus/deficit in 2010 and 2050 for Scenario 8 where fertiliser is reduced from $50 \mathrm{~kg} / \mathrm{ha}$ to $0 \mathrm{~kg} /$ ha under the same $0.5 \%$ rate of crop yield improvement. A comparison of this scenario to Scenario 1 (Fig. 4) illustrates the profound impact of fertiliser on the crop surplus/deficits for all countries. The countries, which have high dependencies on nitrogen fertilisation, show marked drops from surplus in Fig. 4 to deficits in Fig. 5, and include both China and the United States. While a zero rate of nitrogen fertilisation is an extreme assumption, it does show the importance of fertiliser application in terms of feeding the world. To the extent that fertiliser use can impose negative environmental costs on landscapes and planetary nitrogen and phosphorus cycles (Rockström et al. 2009), reductions in its average use must be accompanied by methods of crop production that offset the expected decline in crop yields, such as through nitrogen use efficiency in plants, precision agriculture (Grafton and Yule 2015) and effective use of biological nitrogen fixation. Finding ways to deliver the nitrogen essential to food production, but in ways that do not have negative impacts on the ecological processes and GHG emissions is a significant challenge (Mueller et al. 2014)

Figure 6 shows the relationship between water deficits/ surpluses under three rates of irrigation for each of 19 countries where $\mathrm{N}$ fertiliser was held constant at $50 \mathrm{~kg} / \mathrm{ha}$ and crop productivity improvement was set at about $0.4 \%$ /year to 2050. Increased water use for cropping will, according to our projections, result in water deficits in most countries by 2050. The projected water deficit in cropping can only be eliminated by reducing water demand in other sectors, or by reducing water levels in surface flows and/or groundwater.

The sum of irrigated water use for the 19 countries analysed with $100 \mathrm{~mm}$ of irrigation requires 1,744 billion $\mathrm{m}^{3}$ of water. To achieve rates of irrigation of $200 \mathrm{~mm}$ and $400 \mathrm{~mm}$ over and above existing rates of precipitation would increase water consumption to 3,489 (Scenario 2) and 6,979 (Scenario 3) billion 
Fig. 4 Projected food surplus or deficit (billions kcalories) for the 19 countries examined in 2010 and projected to 2050 for Scenario 1 of dryland and irrigated cropping with $200 \mathrm{~mm} /$ ha of irrigation and $50 \mathrm{~kg} / \mathrm{ha} \mathrm{N}$ fertiliser with a $0.5 \%$ annual crop yield improvement rate or approximately a $20 \%$ increase in yield over the 50 -year period

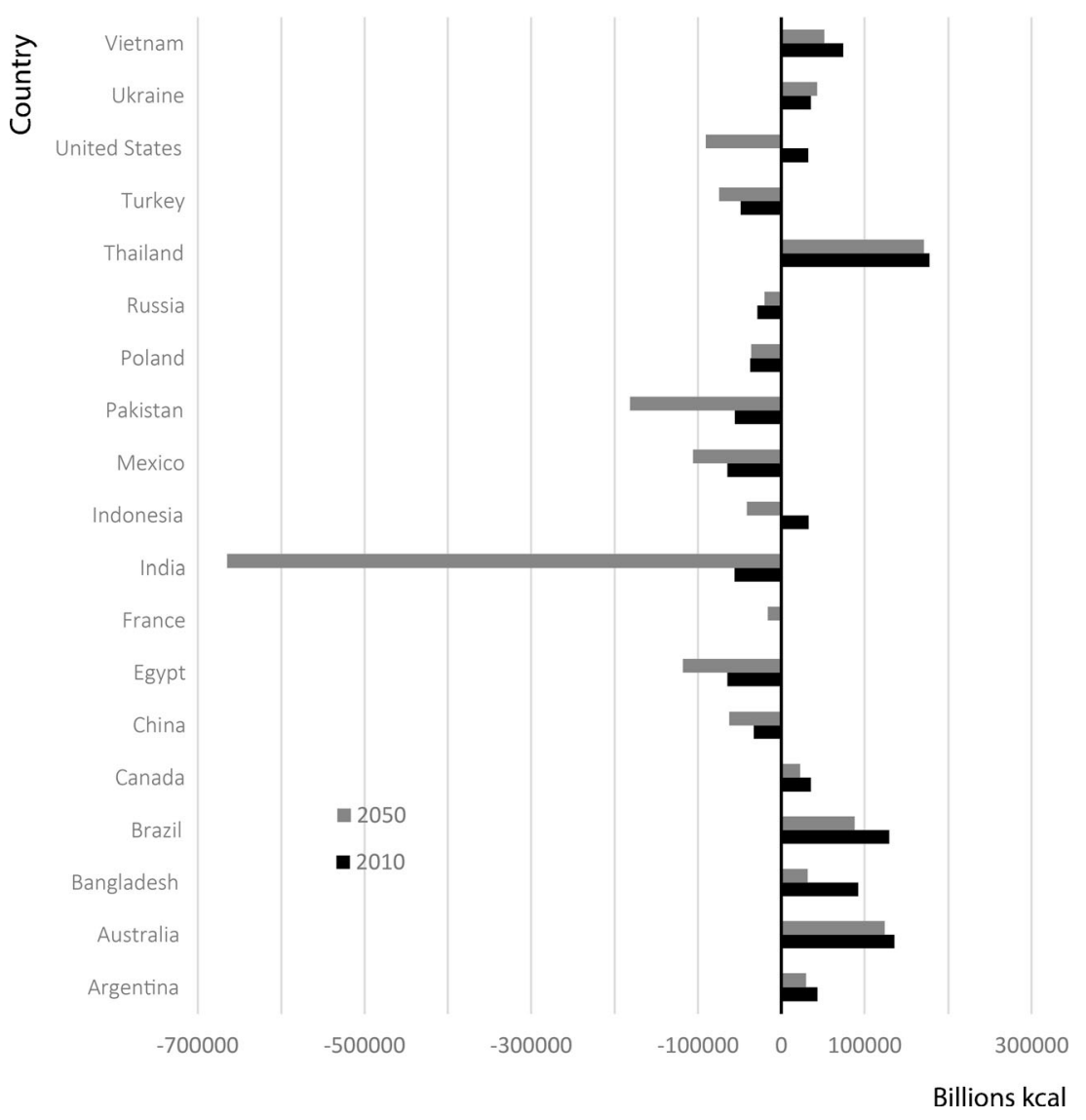

Fig. 5 Projected food surplus or deficit (billions kcalories) for the 19 countries examined in 2010 and projected to 2050 for Scenario 8 for dryland and irrigated cropping with $200 \mathrm{~mm} /$ ha of irrigation and $0 \mathrm{~kg} / \mathrm{ha} \mathrm{N}$ fertiliser with a linear annual rate of crop yield improvement of $0.5 \%$. This is the option of Scenario 8 in the global projections in Fig. 4. One difference between Fig. 5 and Fig. 6 is the use of $50 \mathrm{~kg} / \mathrm{ha}$ of $\mathrm{N}$ fertiliser

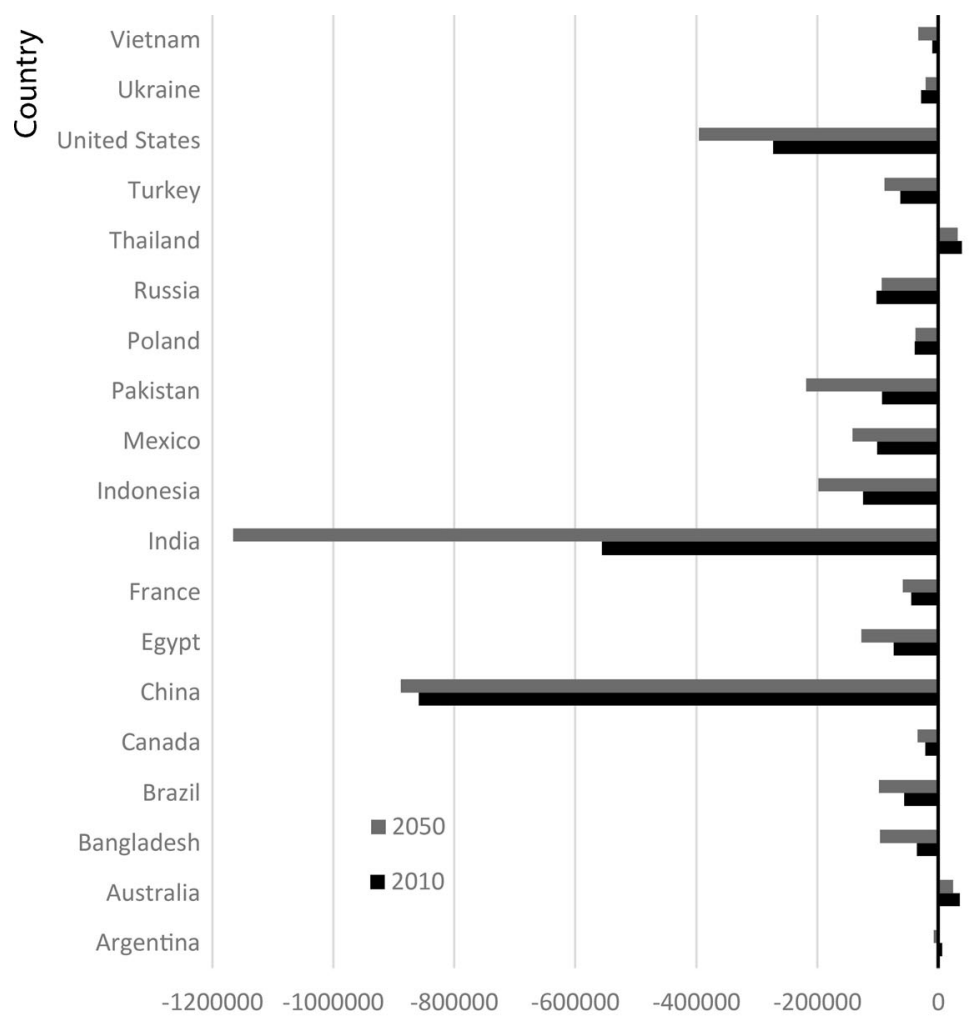

200000

Billions kcal 
Fig. 6 The water supply deficit or surplus (billion cubic meters) for 19 countries in 2050 under options where $\mathrm{N}$ fertiliser was held constant at $50 \mathrm{~kg} / \mathrm{ha}$, crop productivity improvement is at about $0,25 \% /$ year to 2050 and irrigation water was increased from $100 \mathrm{~mm}$ in Scenario 1 to $200 \mathrm{~mm} / \mathrm{ha}$ and $400 \mathrm{~mm} / \mathrm{ha}$ in Scenario 2 , and 3 respectively

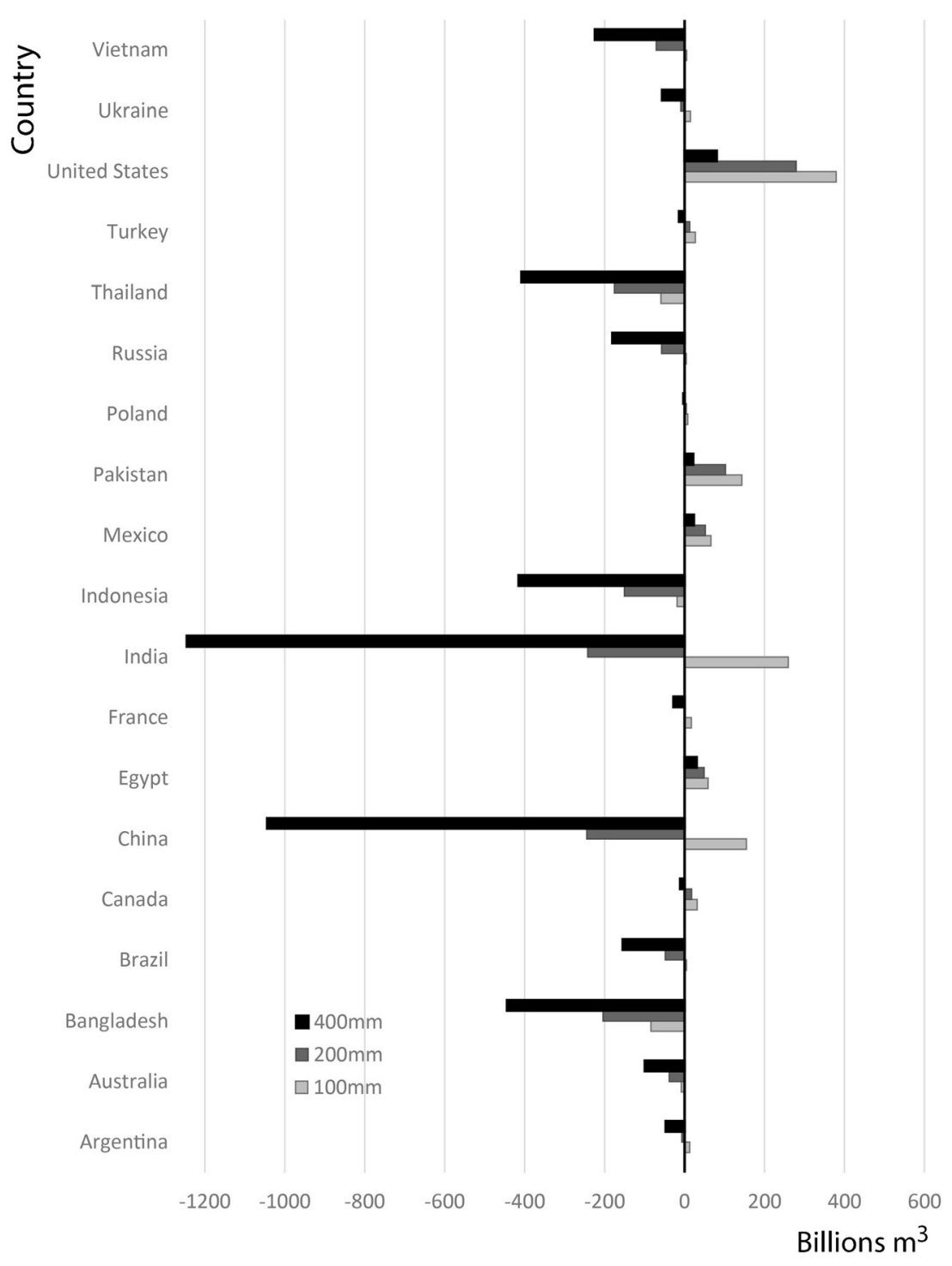

kilocalories rather than absolute levels of crop production and does not include expected future contributions of animal production to diets. As a result, the increase in crop food requirement will almost certainly be greater than our projected value. By comparison, the projected increase in global food requirement computed by Valin et al. (2014) and Tilman et al. (2011) both encompass dietary shifts and indicate that food demand will increase between 59 and $98 \%$ by 2050 . Bajželj et al. (2014) also show how important the type of food demand is in closing the global food gap if increase in GHG emissions, caused by changes in land-use, are to be avoided.

Our findings show the key role that increased inputs, such as fertilisers, play in ensuring that food supply keeps pace with global food demand. The effects of nitrogen fertiliser on the six major crops modelled shows the possibility of increasing crop food supplies if sufficient fertiliser is applied and if annual crop yield improvements are in excess of $0.5 \%$ per year. Our findings are consistent with Rosegrant et al. (2014) and stress the
The GFWS platform provides a means to examine options for food supply and ways to close the gap between food demand and supply by 2050 . Our estimate of the requirement for increased crop food for the 19 countries in the model between 2010 and 2050 is $27 \%$. We stress, however, that this is denoted in 
importance of finding ways to provide fertiliser (Roberts 2009) and nutrient balance (Ciampitti and Vyn 2014) without losses and damage to the local, regional and global environmental processes.

Projections of crop water use indicate the lack of substitutability between average fertiliser use and water use in irrigation. Our preliminary results show that high rates of crop water use (water consumed by the crop) of $400 \mathrm{~mm} / \mathrm{ha}$ is sufficient to put very large demands on water resources and to push global water use, from agriculture alone, and with no other increases in industrial or household use, beyond the estimated safe operating boundary for the planet (Rockström et al. 2009, 2014).

We highlight four key findings. First, we stress the critical importance of nitrogen fertiliser applications to ensure that there is no gap between global food availability and requirements. This result emphasises that, if sustainable intensification of agriculture (Godfray 2015) is to feed more than 9 billion by 2050, the world must find ways, probably with sub-optimal rates of fertiliser use, to maintain and increase crop yields. Second, crop yield improvements of $0.5 \%$ per year or less will generate a food availability deficit out to 2050 on the basis of a $27 \%$ increase in calorie per capita per day by 2050 in the 19 countries modelled in our analysis. If food demand were to increase by at least twice this rate, as projected by several authors, then the minimum crop yield improvements required would be at least $1 \%$ per year. Thus, our results support the findings of others (Fischer et al. 2014) that stress the critical need for appropriate investment in research and development to ensure current rates of yield growth do not fall any further. Third, we project a growing food deficit in South Asia out to 2050 over a range of possible scenarios. Further, food supply projections by country indicate that, even if there were to be sufficient food available in total by 2050 , there will likely be a number of 'choke points'. Thus, food trade will be critically important to ensure an adequate distribution of food across countries. Fourth, the projected water use for irrigated agriculture projects substantial water deficits in key foodproducing countries, including China and India, even in the absence of growth in water demand for non-agricultural purposes.

\section{Conclusions}

Multiple models of food supply and demand are currently available. None of these models are freely accessible in the sense that they can be downloaded and used by persons without any modelling experience. To respond to this 'missing model' problem the Global Food and Water System (GFWS) platform has been developed based on national cropping data (dryland and irrigated) for 19 major food-producing countries. Its 'engine' is the APSIM crop simulation toolbox that has been widely used and tested over the past two decades. Its interface is Excel and is easy to use and can provide users with figures of food supply/demand projections under various scenarios.
While the GFWS platform is very much work in progress, it already provides useful insights about food availability and agricultural water use out to 2050 . These include the importance of fertiliser use to ensure increased crop yields, the need to have ongoing crop yield improvements at least as great as $1 \%$ per year, the likelihood of large national food deficits in some countries, especially South Asia, and the likelihood of not only water extraction exceeding a safe operating space for the globe (Rockström et al. 2014) but also the likelihood of substantial water deficits from agricultural water use alone occurring in key food-producing countries, such as China and India. Further model developments will allow users to explore a greater range of scenarios and to consider additional scenarios regarding the critical determinants of food supply and the effects of meeting global food demand on water use and land use. Overall, our findings support the view that effectively responding to food-energy-environment-water risks will be one of the key global policy challenges of the coming decades.

Acknowledgments This paper was part of a workshop sponsored by the OECD Co-operative Research Programme on Biological Resource Management for Sustainable Agricultural Systems.

Open Access This article is distributed under the terms of the Creative Commons Attribution License which permits any use, distribution, and reproduction in any medium, provided the original author(s) and the source are credited.

\section{References}

Alexandratos, Nikos \& Bruinsma, Jelle (2012). World agriculture towards 2030/2050: the 2012 Revision. ESA Working Paper No. 12-03, June 2012, Agricultural Development Economics Division, Food and Agriculture Organization of the United Nations. www.fao. org/economic/esa. Accessed 12 Feb 2015.

Bajželj, B., Richards, K. S., Allwood, J. M., Smith, P., Dennis, J. S., Curmi, E., \& Gilligan, C. A. (2014). Importance of food-demand management for climate mitigation. Nature Climate Change, 4, 924-929.

Beddington, J. (2010). Food security: contributions from science to a new and greener revolution. Phil. Trans. R. Soc. B, 365, 61-71. doi:10. 1098/rstb.2009.0201.

Bouman, B. A. M., \& Van Laar, H. H. (2006). Description and evaluation of the rice growth model ORYZA2000 under nitrogen-limited conditions. Agricultural Systems, 87, 249-273.

Chartres, C. J., \& Noble, A. (2015). Sustainable intensification: overcoming land and water constraints on food production. Food Security.

Chartres, C., \& Sood, A. (2013). The water for food paradox. Aquatic Procedia, 1, 3-19.

Ciampitti, I. A., \& Vyn, T. J. (2014). Understanding global and historical nutrient use efficiencies for closing maize yield gaps. Agronomy Journal, 106(6), 2107-2117.

FAO (2011a) Global food losses and food waste: extent, causes and prevention. FAO, Rome.

FAO (2011b) Database collection of the Food and Agriculture Organization of the United Nations. Www.faostat.fao.org. Food Balance Sheets. Accessed August 2012, available at http://faostat. fao.org/site/354/default.aspx

Fischer, R. A., Byerlee, D., \& Edmeades, G. O. (2014). Crop yields and global food security: will yield increase continue to feed the world? 
ACIAR Monograph No. 158. Australian Centre for International Agricultural Research, Canberra. 634 pp.

Foley, J. A., Ramankutty, N., Brauman, K. A., Cassidy, E. S., Gerber, J. S., Johnston, M., et al. (2011). Solutions for a cultivated planet. Nature, 478, 337-342.

Foresight. The Future of Food and Farming (2011). Executive Summary. The Government Office for Science, London. https://www.gov.uk/ government/publications/future-of-food-and-farming. Accessed 12 Feb 2015

Gillman, G. P., \& Sumpter, E. A. (1986). Modification to the compulsive exchange method for measuring exchange characteristics of soils. Australian Journal of Soil Research, 24(1), 61-66.

Godfray, C. (2015). The debate over sustainable intensification. Food Security.

Godfray, H. C. J., Beddington, J. R., Crute, I. R., Haddad, L., Lawrence, D., Muir, J. F., et al. (2010). Food Security: the challenge of feeding 9 billion people. Science, 327, 812-818.

Grafton, R. Q., \& Keenan, R.J. (2014). Climate risks: Probabilities, consequences and actions in Economics of Climate Change. Council for the Economic Development of Australia (CEDA).

Grafton, M., \& Yule, I. (2015). The role of technology transfer to improve fertiliser use efficiency. Food Security.

Grassini, P., Eskridge, K. M., \& Cassman, K. G. (2013). Distinguishing between yield advances and yield plateaus in historical crop production trends. Nature Communications, 4(2918), 1-11. doi:10.1038/ ncomms 3918.

IAASTD (2008). Agriculture at the Crossroads. International assessment of agricultural knowledge, science and technology for development (IAASTD): synthesis report with executive summary: a synthesis of the global and sub-global IAASTD reports, McIntyre, Beverly D. (Ed.), Washington, USA: Island Press.

IFPRI (2012a). Food Policy Report in 2012, Chapter 1, http://www.ifpri. org/gfpr/2012/food-policy-2012. Accessed 12 Feb 2015.

IFPRI (2012b). Food Policy Report 2012, Full Report. http://www.ifpri.org/ sites/default/files/publications/gfpr2012.pdf. Accessed 12 Feb 2015.

Ivanic, M., \& Martin, W. (2008). Implications of higher global food prices for poverty in low-income countries. Agricultural Economics, 39, 405- 416.

Keating, B. A., Carberry, P. S., Hammer, G. L., Probert, M. E., Robertson, M. J., Holzworth, D., et al. (2003). An overview of APSIM, a model designed for farming systems simulation. European Journal of Agronomy, 18, 267-288.

McCown, R. L., Hammer, G. L., Hargreaves, J. N. G., Holzworth, D., \& Huth, N. I. (1995). APSIM - an agricultural production system simulation-model for operational-research. Mathematics and Computers in Simulation, 39, 225-231.

McCown, R. L., Hammer, G. L., Hargreaves, J. N. G., Holzworth, P., \& Freebairn, D. M. (1996). APSIM: a novel software system for model development, model testing and simulation in agricultural systems research. Agricultural Systems, 50, 255-271.

Mueller, N. D., West, P. C., Gerber, J. S., MacDonald, G. K., Polasky, S., and Foley, J. A. (2014). A trade-off frontier for global nitrogen use and cereal production, Environ. Res. Lett. 9 (2014) 054002 (8 pp) doi:10.1088/1748-9326/9/5/054002

Muhammad, A., Seale, J. L. Jr., Meade, B., \& Regmi, A. (2011). International Evidence on Food Consumption Patterns: An Update Using 2005 International Comparison Program Data. TB-1929. U.S. Dept. of Agriculture, Economic Research Service.

Nature (29th July 2010). Special edition: can science feed the world? Nature, 466 (7306).

Ray, D. K., Mueller, N. D., West, P. C., \& Foley, J. A. (2013). Yield trends Are insufficient to double global crop production by 2050. PLoS ONE, 8(6), e66428. doi:10.1371/journal.pone.0066428.

Rickson, R. J., Deeks, L. K., Graves, A., Harris, J. A. H., Kibblewhite, M. G., \& Sakrabani, R. (2015). Input constraints to food production: the impact of soil degradation. Food Security - this issue.
Roberts, T. L. (2009). The Role of Fertilizer in Growing the World's Food. Better Crops, 93 (2), 12-15. https://www.ipni.net/ppiweb/ bcrops.nsf/\$webindex/0022BBC19C02604A852575C50062FBB7/ \$file/BC09-2p12.pdf. Accessed 12 Feb 2015.

Rockström, J., Steffen, W., Noone, K., Persson, Å., Chapin, F. S., III, Lambin, E. F., et al. (2009). A safe operating space for humanity. Nature, 461, 472-475.

Rockström, J., Falkenmark, M., Allan, T., Folke, C., Gordon, L., Jägerskog, A., et al. (2014). The unfolding water drama in the anthropocene: towards a resilience-based perspective on water for global sustainability. Ecohydrology, 7, 1249-1261.

Rosegrant, M. W., Koo, J., Cenacchi, N., Ringler, C., Robertson, R., Fisher, M., et al. (2014). Food Security in a World of Natural Resource Scarcity - The Role of Agricultural Technologies. A Peer-Reviewed Publication, International Food Policy Research Institute, Washington, DC, USA, pp. 153, doi. 10.2499/9780896298477

Royal Society (2009). Reaping the Benefits: Science and the Sustainable Intensification of Global Agriculture. London: Royal Society.

Sinn, H.-W. (2012). The green paradox a supply-side approach to global warming. Cambridge: The MIT Press.

Steinbuks, J., \& Hertel, T. W. (2013). Energy prices will play an important role in determining global land use in the twenty first century. Environmental Research Letters, 8(1), 014014. doi:10.1088/1748-9326/8/1/014014.

Tilman, D., Balzer, C., Hill, J., \& Befort, B. L. (2011). Global food demand and the sustainable intensification of agriculture. PNAS, 108(50), 20260-20264.

To, H., \& Grafton, R. Q. (2015). Oil and food prices, biofuels production and food security: Past trends and future challenges. Food Security Mimeograph (in press).

UNEP (2014). Assessing Global Land Use: Balancing Consumption with Sustainable Supply. In: Bringezu, S., Schütz, H., Pengue, W., O’Brien, M., Garcia, F., Sims, R., et al. (Eds.). A Report of the Working Group on Land and Soils of the International Resource Panel. United Nations Environment Programme, Nairobi.

United Nations, Department of Economic and Social Affairs, Population Division (2013). World Population Prospects: The 2012 Revision, Volume II, Demographic Profiles.

Valin, H., Sands, R. D., van der Mensbrugghe, D., Nelson, G. C., Ahammad, H., Blanc, E., et al. (2014). The future of food demand: understanding differences in global economic models. Agricultural Economics, 45, 51-67.

Williams, J., \& McKenzie, F. (2008). Farming without harming. Australasian Science, 29(7), 31-34.

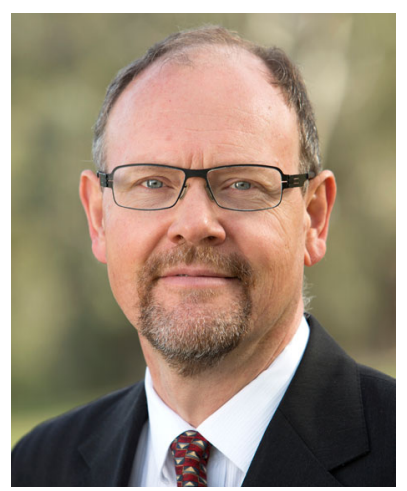

Dr Quentin Grafton is Professor of Economics at the Australian National University (ANU) and adjunct professor at Lincoln University. He is a Fellow of the Academy of Social Sciences of Australia (FASSA) and Chairholder, UNESCO Chair in Water Economics and Transboundary Water Governance. He is the founder of the Global Water Forum (www. globalwaterforum.org), Director of the Food, Energy, Environment and Water Network (www. fe2wnetwork.org/) and Editor in Chief of Policy Forum (www.policyforum.net). He has served in various policy advisory roles including as the Chair of the Socio-economics Reference Group for the Murray-Darling Basin Commission (2008-2009) and is currently the Chair of the Marine Estate Expert Knowledge Panel. 


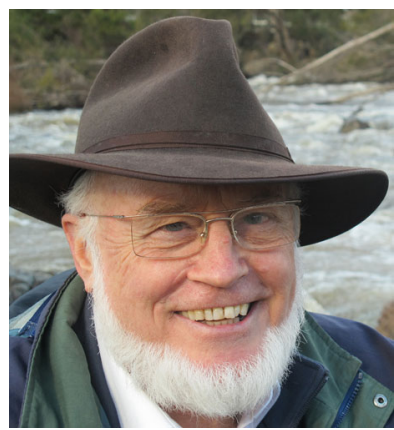

Dr John Williams, FTSE John is a founding member of the Wentworth Group of Concerned Scientists, a Fellow of the Australian Academy of Technological Sciences and Engineering and holds the prestigious Farrer Memorial Medal for achievement and excellence in agricultural science. He is one of Australia's most respected and trusted scientists, with extensive experience in providing national and international thoughtleadership in natural-resource management, particularly in agricultural production and its environmental footprint. John is currently an adjunct professor at ANU Crawford School of Public Policy and adjunct professor at CSU Institute of Land Water and Society.

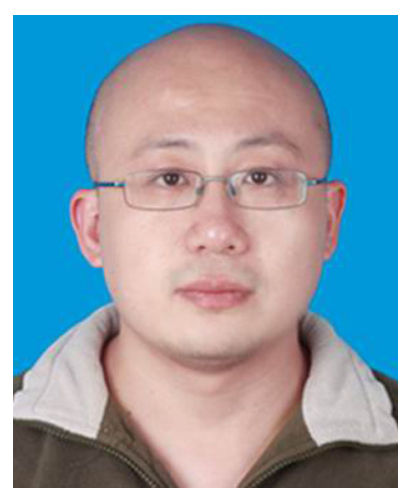

Dr Qiang Jiang is an associate research fellow at Sichuan University, China. He worked for CSIRO in Australia from 2004 2007. In 2013 Qiang Jiang finished his $\mathrm{PhD}$ at the Australian National University. His research focuses on water trading, food security and computer modelling. 